\title{
FGFR4 wt Allele
}

National Cancer Institute

\section{Source}

National Cancer Institute. FGFR4 wt Allele. NCI Thesaurus. Code C52168.

Human FGFR4 wild-type allele is located within 5q35.1-qter and is approximately $11 \mathrm{~kb}$ in length. This allele, which encodes fibroblast growth factor receptor 4 protein, plays a role in the regulation of mitogenesis and differentiation. 